\title{
An Approach to Nasopharyngeal Mass in Newborns: Case Series and Systematic Literature Review
}

\author{
Roee Noy, M.D..,2*, Liron Borenstein-Levin, M.D., ${ }^{2,3}$, and Arie Gordin, M.D., ${ }^{1,2}$ \\ ${ }^{\prime}$ Department of Otolaryngology - Head and Neck Surgery, Rambam Health Care Campus, Haifa, Israel; \\ ${ }^{2}$ The Ruth $E^{2}$ Bruce Rappaport Faculty of Medicine, Technion-Israel Institute of Technology, Haifa, \\ Israel; and ${ }^{3}$ Neonatal Intensive Care Unit, Ruth Rappaport Children's Hospital, Rambam Health Care \\ Campus, Haifa, Israel
}

\begin{abstract}
Objective: Congenital nasopharyngeal masses (CNMs) are rare. Presenting symptoms vary, and the differential diagnoses cover a wide spectrum of possibilities. As it is uncommon, most examples discussed in literature are described as case reports or series. Guidelines on CNM patient management do not exist. In this study, we present two (2) cases of neonates with CNMs that were encountered at our tertiary center. Additionally, to best elaborate a comprehensive, case-based approach to CNM management, we offer an upto-date, diagnosis-to-treatment review of current literature.
\end{abstract}

Methods: Case series and systematic literature review.

Results: Twenty-eight (28) studies are included since January 2000 to October 2021, with a total of 41 cases. Most common diagnosis was teratoma (78\%). Female-to-male ratio was 2.5:1. Twenty percent of cases presented prenatally with polyhydramnios or elevated alpha-fetoprotein. Postnatally, the presenting symptoms most frequently encountered were respiratory distress (78\%), oral mass (52\%), and feeding difficulties (29\%). Seventy-five percent of affected newborns showed symptoms within the first 24 hours of life. Forty percent of cases had comorbidities, especially in the head and neck region.

Conclusions: Congenital nasopharyngeal masses can be detected antenatally, or symptomatically immediately after birth. Airway protection is a cornerstone in the management. Selecting the right imaging

\begin{abstract}
Abbreviations: CNM, congenital nasopharyngeal mass; CT, computed tomography; EXIT, ex-utero intrapartum treatment; MDT, multidisciplinary team; MRI, magnetic resonance imaging; NICU, neonatal intensive care unit.

Citation: Noy R, Borenstein-Levin L, Gordin A. An Approach to Nasopharyngeal Mass in Newborns: Case Series and Systematic Literature Review. Rambam Maimonides Med J 2022;13 (1):eooo6. Review. doi:10.5041/RMMJ.10463

Copyright: (C) 2022 Noy et al. This is an open-access article. All its content, except where otherwise noted, is distributed under the terms of the Creative Commons Attribution License (http://creativecommons.org/licenses/by/3.0), which permits unrestricted use, distribution, and reproduction in any medium, provided the original work is properly cited.
\end{abstract}

Conflict of interest: No potential conflict of interest relevant to this article was reported.

* To whom correspondence should be addressed. E-mail: roeenoy@gmail.com or R NOY@rambam.health.gov.il 
modality and convening a multidisciplinary team meeting are important toward the planning of next steps/therapeutic approach. Typically, a transnasal or transoral surgical approach will be deemed sufficient to address the problem, with a good overall prognosis.

KEY WORDS: Congenital nasopharyngeal mass, glioma, heterotopic brain tissue, teratoma

\section{INTRODUCTION}

The nasopharynx-the embryonic intersection of the neural axis and alimentary and respiratory tracts-is subject to a variety of congenital anomalies. Congenital head and neck irregularities are rare, with a 5.5\% prevalence among all congenital anomalies. ${ }^{1}$ Congenital nasopharyngeal masses (CNMs) can be divided into two categories, such as benign neoplasm versus malignant neoplasm (Table 1). ${ }^{2}$

As opposed to anterior nasal masses, which are usually seen on external examination of the nose, posterior nasal cavity and nasopharyngeal masses are often difficult to visualize. Moreover, CNM diagnosis can be delayed since signs and symptoms are seldom specific and may mimic other upper respiratory tract problems. However, while feeding difficulties may be the only presenting symptom in patients with smaller lesions, larger CNMs usually present with acute respiratory distress and may require emergent airway protection. Therefore, as newborns are obligate nasal breathers, it is essential to quickly diagnose and treat situations with nasopharyngeal obstruction.

Due to the rarity of cases, most CNMs described in the literature are case reports or series. This study presents two cases treated in our tertiary center, along with a systematic review of the current literature. Our purpose is to offer an up-to-date, casebased approach to CNM management, from diagnosis to treatment.

\section{CASE PRESENTATION \#1}

A 3400-g female neonate was born to a primigravida, healthy mother, by a vaginal delivery, at $40+1$ weeks' gestation. Delivery was uneventful, with 9/10 Apgar scores and normal physical exam. Prenatal evaluation revealed polyhydramnios, which was attributed to gestational diabetes. During the first hours of life, dyspnea, desaturation events during feeding, and increased salivation were noticed. A nasogastric tube passed with difficulty through both nostrils; therefore an anatomical blockage was sus- pected. Nasal endoscopy was performed and revealed a nasopharyngeal mass. Protective intubation was performed, and the neonate was then transferred to our neonatal intensive care unit (NICU). Magnetic resonance imaging (MRI) revealed a heterogeneous lesion bulging from the nasopharynx into the oropharynx and the base of tongue, which resembled radiographically a teratoma (Figure 1). A biopsy, performed under general anesthesia, suggested the presence of glial tissues, a component of teratoma. Three days later, a transoral surgical coblation procedure was carried out. The completion of the resection included a transnasal part, which resulted in a fully macroscopic excision and patent airway. The neonate was extubated on postoperative day 1, with no respiratory symptoms or feeding problems, and was discharged from the hospital on postoperative day 3 . The final histopathological report revealed a mature teratoma. Follow-up one month after surgery was unremarkable, with no evidence to suggest recurrence.

\section{CASE PRESENTATION \#2}

Two days old, a male neonate presented with feeding and breathing difficulties. Physical examination was normal except for mild dyspnea and microretrognathia. Desaturation and dyspnea were relieved when the neonate was placed prone after insertion of a nasal airway. History revealed an uneventful pregnancy and spontaneous vaginal delivery at $38+6$ weeks' gestation, with a birth weight of 3785 g. Prenatal evaluation was normal. Laboratory studies and echocardiography were normal, and the neonate was transferred to our NICU for further evaluation for upper airway obstruction. Upon arrival, a nasal endoscopy exam was performed, revealing a cystic mass blocking the nasopharynx and the soft palate. A neck ultrasound (US) demonstrated a midline cystic mass posterior to the tongue. Brain US was unremarkable. Head and neck MRI demonstrated an elliptical, cystic, well-defined mass with fluid content and a stipe with partition extending from the posterior aspect of the nose to the oropharynx (Figure 2). 
Table 1. Differential Diagnosis, Congenital Nasopharyngeal Mass (CNM).

\begin{tabular}{|c|c|}
\hline $\begin{array}{l}\text { Type of } \\
\text { Neoplasm }\end{array}$ & Differential Diagnosis \\
\hline \multirow{18}{*}{$\begin{array}{l}\text { Benign } \\
\text { Neoplasm }\end{array}$} & Adenoid tissue or retention cyst* \\
\hline & Aneurysmal bone cyst \\
\hline & Angiofibroma \\
\hline & Antrochoanal polyp* \\
\hline & Ectopic pituitary \\
\hline & Fibrous dysplasia \\
\hline & First branchial pouch cyst* \\
\hline & Giant cell tumor \\
\hline & Hairy polyp* \\
\hline & Hemangioma \\
\hline & Heterotopic brain tissue (e.g. cephalocele, glioma) \\
\hline & Mucocele* \\
\hline & Pleomorphic adenoma \\
\hline & Pyogenic granuloma* \\
\hline & Salivary hamartoma \\
\hline & Sinonasal polyp* \\
\hline & Teratoma (can be malignant) \\
\hline & Thornwaldt cyst* \\
\hline \multirow{5}{*}{$\begin{array}{l}\text { Malignant } \\
\text { Neoplasm }\end{array}$} & Carcinoma \\
\hline & Esthesioneuroblastoma \\
\hline & Hematological malignancies (e.g. lymphoma, leukemia) \\
\hline & Metastases (e.g. neuroblastoma) \\
\hline & Rhabdomyosarcoma \\
\hline
\end{tabular}

* Cystic/Polypoid benign neoplasm

As well-defined planes were observed between the mass and its adjutant structures, no biopsy was taken preoperatively. Transnasal endoscopic surgery was carried out to fully resect macroscopically a cystic nasopharyngeal mass. Extending from the roof of the nasopharynx to the soft palate, the mass, which presented with some liquid and liquefactive properties during surgery, was entirely blocking passage to the choana. Due to epistaxis, postoperative care required the administration of one blood unit and a local tamponade with tranexamic acid. The neonate was extubated on postoperative day 2. Mild stridor was treated with budesonide inhalation. On postoperative day 7 , the neonate was discharged home with no feeding or respiratory symptoms.
Later, on histopathological exam, the tumor was found to be positive for glial fibrillary acidic protein, suggesting the presence of brain, and the diagnosis of heterotopic brain tissue, which is similar to nasal glioma, was confirmed. Twelve months after surgery, the child was examined in our follow-up clinic for noisy breathing and snoring. Nasal endoscopy and MRI showed nasopharyngeal midline tissue, which was suspicious for enlarged adenoid tissue. Endoscopic excision of the tissue was performed, during which time no other suspicious nasopharyngeal mass was observed. Pathology report confirmed that the tissue consisted of epithelium and fibrotic stroma, which was consistent with adenoid hypertrophy. 

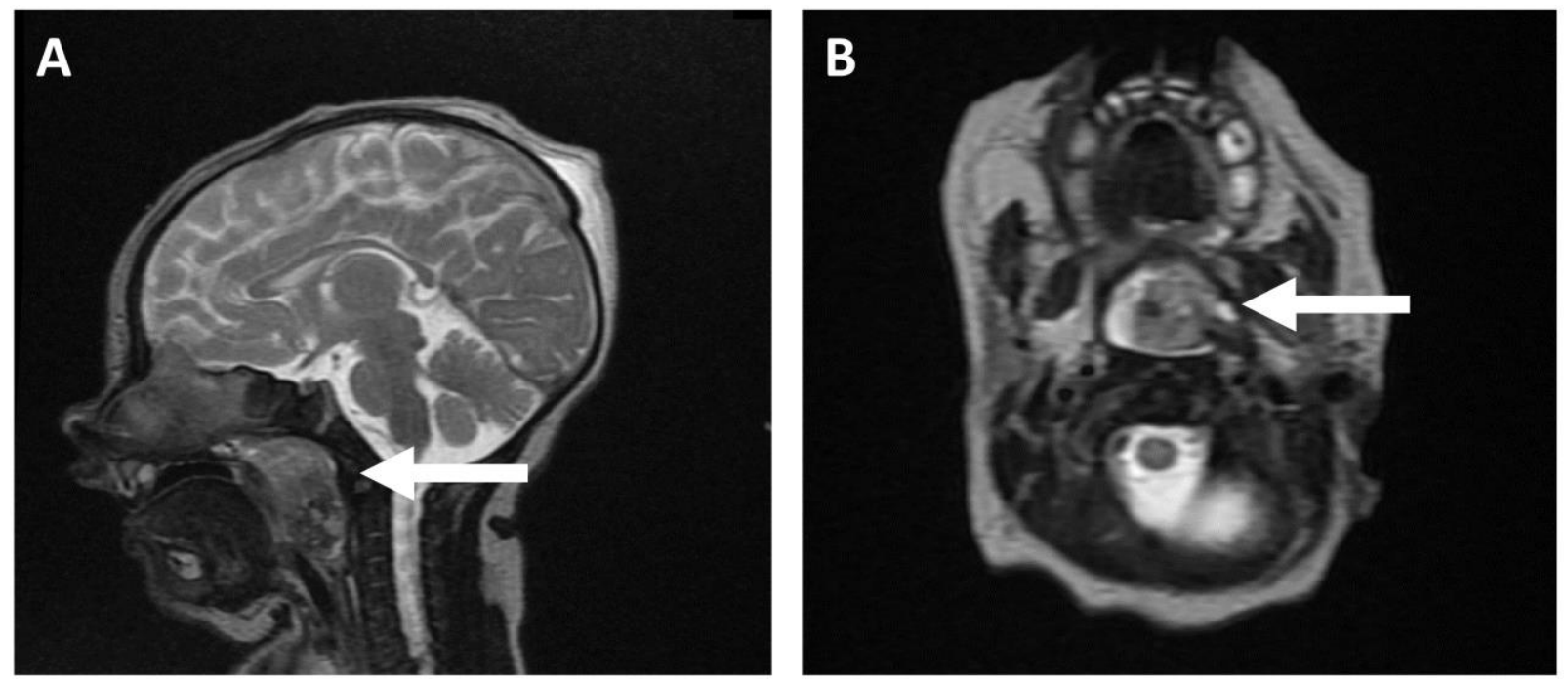

Figure 1. MRI with a Nasopharyngeal Mass Bulging into the Oropharynx and the Base of Tongue, with No Intracranial Involvement.

A: The lesion consists of restricted areas, areas with decreased susceptibility-weighted imaging (SWI) values. B: Posteriorly, there is a $0.5 \mathrm{~cm}$ area with a high T1-weighted signal, and a medium-to-low signal on fatsuppression.
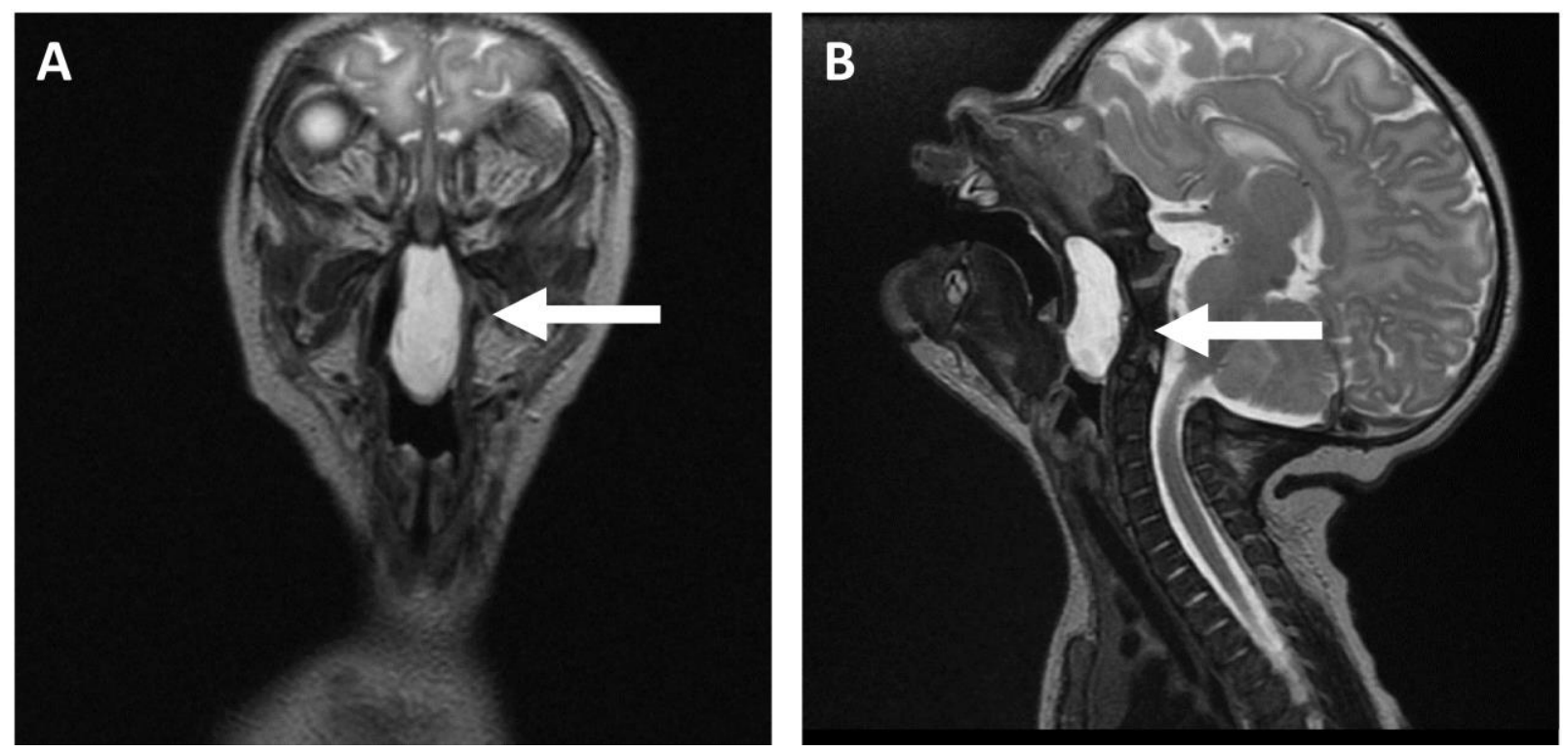

Figure 2. MRI with a Midline Nasopharyngeal Cystic-elliptical Mass, with Well-defined Borders and No Intracranial Involvement.

A: Lesion begins in the posterior aspect of the nose and reaches the oropharynx. B: Sagittal plane. 


\section{LITERATURE REVIEW}

The goal of our systematic review was to find and discuss congenital nasopharyngeal masses (CNMs), as this topic is not well described in literature, and no management guidelines exist.

\section{Methods}

According to the Preferred Reporting Items for Systematic Reviews and Meta-Analyses (PRISMA) statement, we searched PubMed, Embase, MEDLINE, and Google Scholar from January 2000 to October 2021 using the following search terms: "congenital nasopharyngeal mass" (or tumor or lesion), or "teratoma," "heterotopic neuroglial tissue," "brain tissue," or "cephalocele." From this, we identified 153 citations and fully reviewed reports (Figure 3). After excluding duplications, alternative diagnoses, and articles not in English, we had 22 case reports and 6 case series, for a total of 28 studies (41 cases) for inclusion in our review (Table 2). One reviewer screened each report retrieved. In each report we collected number of cases, gender, age, presenting symptoms, management, need for airway protection, usage of antibiotics or additional treatments, final histopathology report, and long-term follow-up or prognosis. Risk of bias in each study was relatively small as studies only discuss their own case reports or series, and no statistical analysis was required.

\section{Results}

The most common diagnoses for CNMs were teratomas (78\%, 32 patients) followed by hairy polyp (7\%, 3 patients). Twenty percent of cases presented prenatally with either polyhydramnios or elevated alphafetoprotein levels. Female-to-male ratio was 2.5:1. Biopsies were performed in $25 \%$ of cases.

The most common presenting symptoms were respiratory distress $(78 \%)$, oral mass $(52 \%)$, and feeding difficulties (29\%). There was a combination of symptoms in $33 \%$.

Seventy-five percent of patients showed symptoms within the first 24 hours of life, $10 \%$ within the first month, and the rest within the first year.

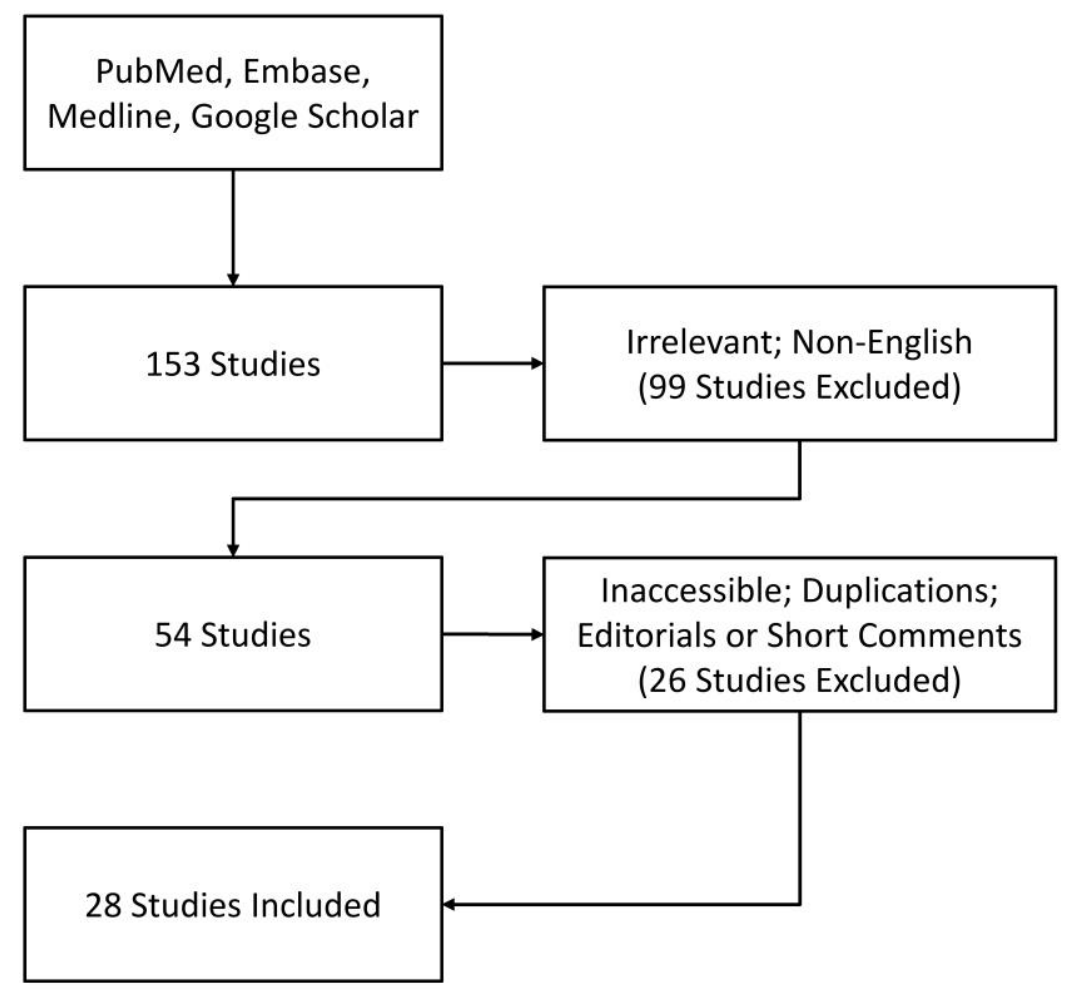

Figure 3. Systematic Literature Review Methodology. 
Table 2. Case Reports and Series of Congenital Nasopharyngeal Masses (CNMs).

\begin{tabular}{|c|c|c|c|c|c|c|c|c|}
\hline Authors & Year & Country & Cases & Sex & Age & Symptoms & Pathology & Comments \\
\hline Coppit et al. ${ }^{3}$ & 2000 & USA & 3 & $M, F$ & Birth & $\mathrm{RD}, \mathrm{FD}, \mathrm{OM}$ & $\begin{array}{l}\text { Dermoid, } \\
\text { teratoma }\end{array}$ & $\begin{array}{l}\text { Prenatal alpha- } \\
\text { fetoprotein and } \\
\text { ultrasound, } \\
\text { recurrence after } 5 \\
\text { months }\end{array}$ \\
\hline Behar et al. ${ }^{4}$ & 2001 & USA & 1 & M & Birth & $\mathrm{RD}$ & $\begin{array}{l}\text { Heterotopic } \\
\text { neuroglial } \\
\text { tissue }\end{array}$ & Tracheostomy \\
\hline Uchino et al. ${ }^{5}$ & 2001 & Japan & 1 & $\mathrm{~F}$ & Birth & $\mathrm{OM}$ & Teratoma & $\begin{array}{l}\text { Syndrome, } \\
\text { dysmorphism }\end{array}$ \\
\hline $\begin{array}{l}\text { Andronikou et } \\
\text { al. }{ }^{6}\end{array}$ & 2003 & Australia & 3 & & Birth & $\mathrm{RD}$ & Teratoma & $\begin{array}{l}\text { Polyhydramnios, } \\
\text { prenatal MRI, } \\
\text { EXIT procedure }\end{array}$ \\
\hline $\operatorname{Roh}^{7}$ & 2004 & Korea & 1 & $\mathrm{~F}$ & $7 \mathrm{mo}$ & $\begin{array}{l}\text { Snoring, } \\
\text { sleep apnea }\end{array}$ & Hairy polyp & $\begin{array}{l}\text { Adjacent to } \\
\text { eustachian tube }\end{array}$ \\
\hline $\begin{array}{l}\text { Abdulkader et } \\
\text { al. } 8\end{array}$ & 2006 & Qatar & 1 & $\mathrm{~F}$ & $3 \mathrm{mo}$ & $\mathrm{RD}$ & Hairy polyp & Comorbidity \\
\hline Freitas et al. ${ }^{9}$ & 2007 & Brazil & 2 & $M, F$ & Birth & $\mathrm{RD}, \mathrm{OM}$ & Teratoma & \\
\hline $\begin{array}{l}\text { Hossein \& } \\
\text { Mohammad }^{10}\end{array}$ & 2007 & Iran & 1 & $\mathrm{~F}$ & Birth & $\mathrm{OM}$ & Teratoma & $\begin{array}{l}\text { Prenatal alpha- } \\
\text { fetoprotein, } \\
\text { comorbidity }\end{array}$ \\
\hline Maartens et al. ${ }^{11}$ & 2009 & Netherlands & 1 & M & Preterm & $\begin{array}{l}\mathrm{RD} \text {, nasal } \\
\text { mass }\end{array}$ & Teratoma & $\begin{array}{l}\text { Prenatal alpha- } \\
\text { fetoprotein, } \\
\text { polyhydramnios, } \\
\text { intubation }\end{array}$ \\
\hline Turnbull et al. ${ }^{12}$ & 2009 & UK & 1 & $\mathrm{~F}$ & Preterm & OM & Teratoma & $\begin{array}{l}\text { Prenatal } \\
\text { ultrasound, } \\
\text { comorbidity }\end{array}$ \\
\hline Tiwari et al. ${ }^{13}$ & 2009 & India & 1 & $\mathrm{~F}$ & Birth & $\begin{array}{l}\mathrm{RD}, \\
\text { cyanosis }\end{array}$ & Teratoma & \\
\hline He et al. ${ }^{14}$ & 2010 & China & 2 & $M, F$ & Birth & $\mathrm{RD}, \mathrm{FD}, \mathrm{OM}$ & Teratoma & Comorbidity \\
\hline $\begin{array}{l}\text { Mirshemirani et } \\
\text { al. }{ }^{15}\end{array}$ & 2011 & Iran & 1 & $\mathrm{~F}$ & Birth & $\mathrm{FD}, \mathrm{OM}$ & Teratoma & Comorbidity \\
\hline Chariker et al. ${ }^{16}$ & 2011 & USA & 1 & $\mathrm{~F}$ & $3 d$ & FD & Teratoma & $\begin{array}{l}\text { Comorbidities, } \\
\text { pituitary } \\
\text { duplication }\end{array}$ \\
\hline $\begin{array}{l}\text { Rangachari et } \\
\text { al. }{ }^{17}\end{array}$ & 2012 & India & 1 & $M$ & $5 d$ & $\mathrm{RD}$ & Teratoma & $\begin{array}{l}\text { Multiple } \\
\text { intubations }\end{array}$ \\
\hline Koike et al. ${ }^{18}$ & 2013 & Japan & 1 & $\mathrm{~F}$ & $3 \mathrm{mo}$ & $\mathrm{RD}$ & Hairy polyp & Respiratory failure \\
\hline Bayır et al. ${ }^{19}$ & 2014 & Turkey & 1 & $M$ & Birth & $\mathrm{RD}$ & Teratoma & $\begin{array}{l}\text { Polyhydramnios, } \\
\text { multiple biopsies }\end{array}$ \\
\hline Han et al. ${ }^{20}$ & 2014 & Korea & 1 & $M$ & Preterm & $\mathrm{RD}, \mathrm{FD}, \mathrm{OM}$ & Teratoma & $\begin{array}{l}\text { Comorbidities, } \\
\text { 2-step surgery }\end{array}$ \\
\hline Mann et al. ${ }^{21}$ & 2014 & UK & 3 & $\mathrm{~F}$ & Birth & $\mathrm{RD}, \mathrm{FD}, \mathrm{OM}$ & Choristoma & \\
\hline
\end{tabular}

Continued on next page. 
Table 2 (continued).

\begin{tabular}{|c|c|c|c|c|c|c|c|c|}
\hline Authors & Year & Country & Cases & Sex & Age & Symptoms & Pathology & Comments \\
\hline $\begin{array}{l}\text { Radhakrishnan } \\
\text { et al. } 22\end{array}$ & 2015 & India & 1 & $\mathrm{~F}$ & Birth & & $\begin{array}{l}\text { Salivary gland } \\
\text { anlage tumor }\end{array}$ & $\begin{array}{l}\text { Prenatal MRI, } \\
\text { EXIT procedure }\end{array}$ \\
\hline $\begin{array}{l}\text { Menezes \& } \\
\text { Simao }^{23}\end{array}$ & 2015 & Brazil & 1 & & Preterm & $\mathrm{RD}, \mathrm{OM}$ & Teratoma & $\begin{array}{l}\text { Prenatal } \\
\text { ultrasound, } \\
\text { polyhydramnios }\end{array}$ \\
\hline Hwang et al. ${ }^{24}$ & 2015 & Australia & 1 & $\mathrm{~F}$ & Birth & $\mathrm{RD}, \mathrm{OM}$ & Teratoma & $\begin{array}{l}\text { Polyhydramnios, } \\
\text { tracheostomy, } \\
\text { coblation, biopsy } \\
\text { with wrong } \\
\text { diagnosis }\end{array}$ \\
\hline $\begin{array}{l}\text { Alexander et } \\
\text { al. }{ }^{25}\end{array}$ & 2015 & UK & 6 & $M, F$ & Birth & $\mathrm{RD}, \mathrm{FD}, \mathrm{OM}$ & Teratoma & $\begin{array}{l}\text { Hyponasal speech, } \\
\text { intubation }\end{array}$ \\
\hline Ghatage et al. ${ }^{26}$ & 2016 & India & 1 & $\mathrm{~F}$ & $3 d$ & $\mathrm{RD}, \mathrm{FD}$ & Teratoma & $\begin{array}{l}\text { Comorbidities, } \\
\text { tracheostomy }\end{array}$ \\
\hline Jadhav et al. ${ }^{27}$ & 2017 & India & 1 & $\mathrm{~F}$ & Birth & $\mathrm{RD}, \mathrm{OM}$ & Teratoma & \\
\hline Thong et al. ${ }^{28}$ & 2018 & Malaysia & 1 & $\mathrm{~F}$ & $24 \mathrm{~h}$ & $\mathrm{RD}, \mathrm{OM}$ & Teratoma & $\begin{array}{l}\text { Prenatal alpha- } \\
\text { fetoprotein, } \\
\text { comorbidities, } \\
\text { delayed surgery }\end{array}$ \\
\hline $\begin{array}{l}\text { Aramesh et } \\
\text { al. } 29\end{array}$ & 2020 & Iran & 1 & $\mathrm{~F}$ & Birth & $\mathrm{RD}, \mathrm{OM}$ & Teratoma & Polyhydramnios \\
\hline $\begin{array}{l}\text { Kobayashi et } \\
\text { al. }{ }^{30}\end{array}$ & 2020 & Japan & 1 & M & Birth & $\mathrm{RD}$ & Teratoma & $\begin{array}{l}\text { Prenatal alpha- } \\
\text { fetoprotein, } \\
\text { maxillectomy due } \\
\text { to recurrence }\end{array}$ \\
\hline
\end{tabular}

d, days; EXIT, ex-utero intrapartum treatment; F, female; FD, feeding difficulties; $h$, hours; $M$, male; mo, months; MRI, magnetic resonance imaging; OM, oral mass; RD, respiratory distress; US, ultrasound.

Imaging was used in $72 \%$ of cases (30 patients)of these, $55 \%$ had a computed tomography (CT) scan, and $45 \%$ had MRI. In $20 \%$ of cases, both modalities were used.

Forty-one percent of cases (17 patients) had comorbidities, especially in the head and neck region: of them $60 \%$ had cleft palate, $30 \%$ were found to have systemic diseases (Pierre Robin sequence, West syndrome), and about $10 \%$ of patients had anatomical abnormalities (e.g. micrognathia). Fifty percent of cases occurred in developing countries.

\section{DISCUSSION}

The nasopharynx represents the most superior portion of the pharynx, bounded superiorly by the skull base and inferiorly by the soft palate, and is lined by stratified squamous epithelium and by respiratory epithelium at the roof and nasal choanae. The nasopharynx derives from the neural crests of the ecto- dermal leaflet. ${ }^{2}$ As it is the embryonic intersection of the neural axis and the alimentary and respiratory tracts, the nasopharynx is subjected to a variety of congenital anomalies.

In the literature CNMs are rare, and most research is based on case reports and series. The purpose of this study was to review relevant cases in a select body of literature and to develop a diagnostic approach to CNMs, regardless of the histopathological type of the mass.

We presented two cases of newborns who were admitted to our hospital with CNMs leading to airway obstruction. Both cases were managed similarly, although the final histopathological reports revealed different tumor types. In our literature review, most CNM cases were teratomas, but other tumors were described as well. Based on the cases we presented and our systematic literature review, we 
suggest the following approach to CNM management (Figure 4).

Prenatally, CNMs may present with polyhydramnios due to impaired swallowing.6,11,19,23,24,29 Elevated maternal alpha-fetoprotein levels may also be present. ${ }^{10,11,17,30}$ Ultrasound may detect these lesions. ${ }^{12,23}$ When a suspicion is raised from an ultrasound, a fetal MRI is highly recommended.6,22

Any lesion, especially in the head and neck area, requires referral to a genetic consultation. Parents should be referred to a tertiary hospital with an adequate team of anesthesiologists, neonatologists, and neonatal intensive care unit that can be prepared to carry out a potentially complicated airway management. Prenatal diagnosis also enables planning for an ex-utero intrapartum treatment (EXIT) procedure to secure a newborn's airway before division of the maternal-fetal circulation in cases of large lesions. ${ }^{6,22}$ However, in most cases the EXIT procedure is probably unnecessary. Potential risks include anesthetic challenges and postpartum hemorrhage. The fact that most of the analyzed cases occurred in developing countries raises a concern regarding prenatal diagnostic processes in those countries.

The most common presenting symptoms for CNMs in these infants were respiratory distress, oral mass, and feeding difficulties. Airway protection is, therefore, a cornerstone in the management of CNMs. In a newborn who is suspected of upper airway obstruction, a blocking mass should be suspected. Otolaryngology consultation is advised, and pre-

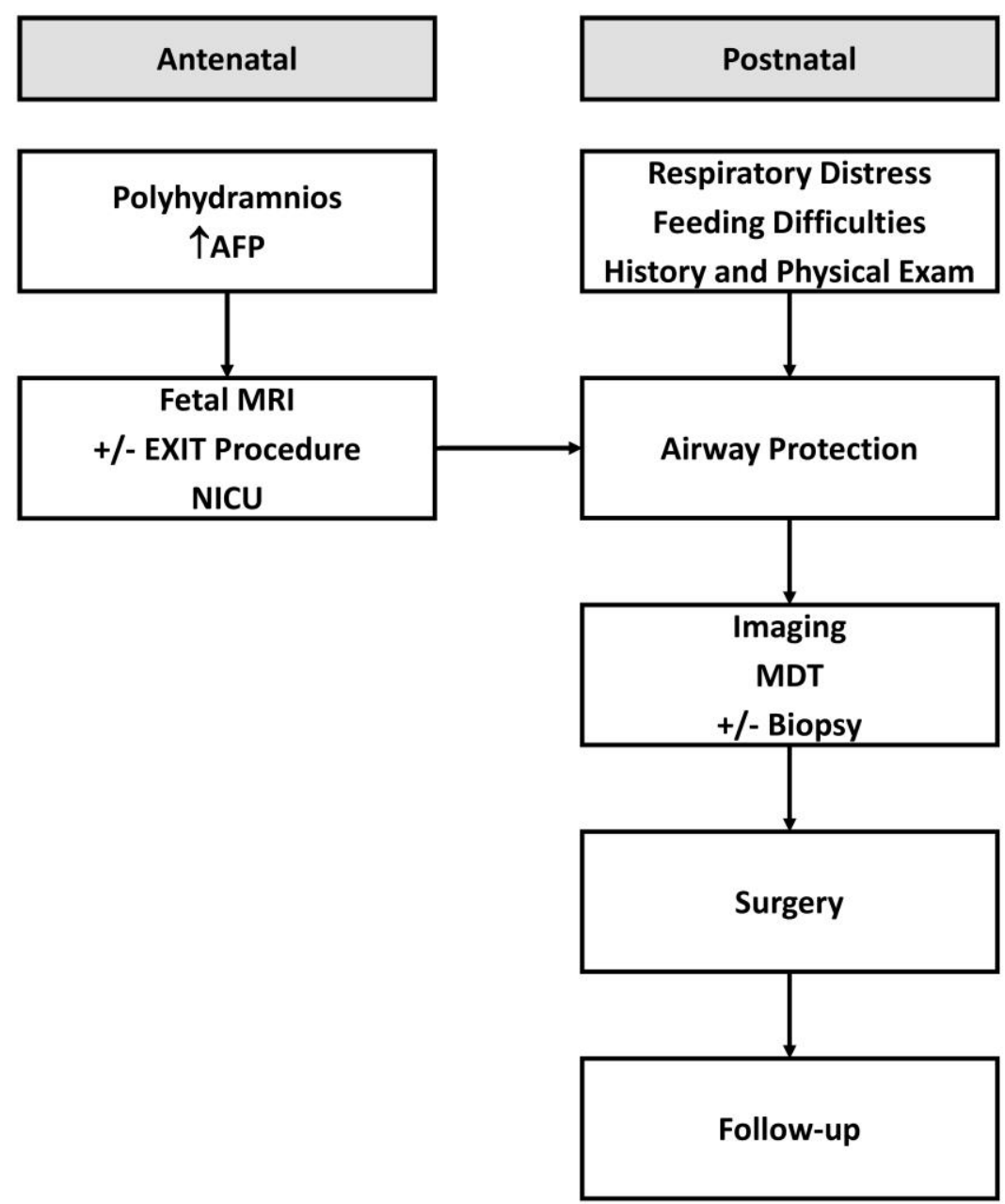

Figure 4. Schematic Approach to a Congenital Nasopharyngeal Mass (CNM) in a Newborn. AFP, alpha-fetoprotein; EXIT, ex-utero intrapartum treatment; MDT, multidisciplinary team; MRI, magnetic resonance imaging; NICU, neonatal intensive care unit. 
ventive intubation should be considered. In the case of a difficult intubation, placement of a tracheostomy tube is advisable.

Although no such cases were described in the literature, it should be mentioned that CNMs can block the eustachian tube and potentially cause serous otitis media.

Prior to delivery of a child with CNM, it is highly advisable to convene a multidisciplinary team (MDT) consisting of neonatologists, otolaryngologists (head and neck surgeons), radiologists, and anesthesiologists. Following the birth, the group should meet again and discuss the next steps.

Selecting the appropriate imaging modality is mandatory. The purpose of imaging is to better acquaint physicians with the components of a given lesion and its relation to adjacent structures, especially the dura mater and the brain. Although an MRI with contrast agent is the recommended modality-as it easily distinguishes different types of tissues and offers reduced radiation exposure in comparison to a CT-its limited availability, long duration, and the need for patient sedation are disadvantages. A CT with contrast agent is an alternative, but its execution may require sedation, as well, and is associated with increased lifetime risk for cancer mortality (as follow-up imaging tests may be necessary). Based on our literature review, we conclude that it is not advisable to perform any CNM-related surgery without imaging, as it will increase the chances for incomplete resection, major bleeding, or adverse outcomes. When there is a concern regarding synchronic malformations, neonatologists may also require additional imaging tests.

A presurgical biopsy can inform physicians about the characteristics of a given lesion and its level of aggressiveness, as well as guide their decisionmaking regarding the extent of resection necessary, the need for additional surgeries, follow-up period intervals, and the need for adjuvant therapies. Due to the fear of bleeding or cerebrospinal fluid leak, it is not recommended to biopsy a vascularized lesion or one with a direct connection to the dura (thus reinforcing the need for imaging before proceeding to a final diagnosis and surgical remedies). As only $25 \%$ of cases in the analyzed literature were biopsied before surgery, the question may be raised whether a presurgical biopsy is necessary at all. Knowing the characteristics and aggressiveness of the mass can dictate the extent and the importance of macroscopically negative margin. Regardless, sometimes the urgent need for surgery can overcome the usefulness of carrying out a biopsy.

Fiberoptic intubation is the preferred technique for establishing airway access in patients with suspected masses that bulge to the oropharynx; nasal intubation is not advised as the nasopharyngeal mass may be injured, resulting in bleeding. Surgeons must be prepared with an option of surgical airway (tracheostomy) in case of failed intubation, especially in patients with large lesions. Tracheostomy techniques in newborns require experienced teams and is beyond the scope of our article.

Depending on the extent of a given mass, several surgical approaches are accepted. Most cases in the studied literature were handled via the transnasal approach or combined with the transoral approach. However, recurrent or aggressive tumors may require a more definite approach or even open surgery. Once again, airway management requires a multidisciplinary approach (anesthesiologists, neonatalogists, and otolaryngologists).

Parents of newborns must be included in the process of decision-making and choosing treatment options.

If preoperative imaging suggests an isolated mass with no relation to brain or dura mater, there is a low risk for meningitis or other major infectious sequelae. Based on systematic literature review, postoperative prophylactic antibiotic was not indicated, unless symptoms of infection (ill-appearing child, fever, neutrophilic leukocytosis, elevated Creactive protein or erythrocyte sedimentation rate) were encountered. However, it should be noted that many authors did not discuss whether they opted to administer preoperative antibiotics, and this point should be treated with caution.

Most cases either placed low emphasis on or did not document the need for follow-ups. Nevertheless, we believe regular follow-up visits are important, especially during the first few years after resection. In cases where lesions have not been fully resected, attentive follow-ups are absolutely indicated.

Due to the rarity of cases, most CNMs are described in literature as case reports, and prospective studies are almost impossible to manage in these patients. In most cases, the prognosis is good. It is important to refer and manage these cases in tertiary centers and to involve MDTs in decisionmaking processes. 
This is the first study to conduct a systematic literature review on this topic. In it, we have recommended an approach for managing newborns with CNMs based on our experience and updated literature review (Figure 4).

\section{REFERENCES}

1. Assiry AA, Khan SD, Al-Shubrmi HR, et al. Head and neck congenital anomalies in neonate hospitals in Hail, Saudi Arabia. Int J Clin Pediatr Dent 2020;13: 160-2. CrossRef

2. Rodriguez DP, Orscheln ES, Koch BL. Masses of the nose, nasal cavity, and nasopharynx in children. Radiographics 2017;37:1704-30. CrossRef

3. Coppit GL 3rd, Perkins JA, Manning SC. Nasopharyngeal teratomas and dermoids: a review of the literature and case series. Int J Pediatr Otorhinolaryngol 2000;52:219-27. CrossRef

4. Behar PM, Muller S, Gerber ME, Todd NW. Heterotopic neuroglial tissue causing airway obstruction in the newborn. Arch Otolaryngol Head Neck Surg 2001;127:997-1002. CrossRef

5. Uchino A, Sawada A, Takase Y, Fujita I, Kudo S. Extreme fenestration of the basilar artery associated with cleft palate, nasopharyngeal mature teratoma, and hypophyseal duplication. Eur Radiol 2002;12: 2087-90. $\underline{\text { CrossRef }}$

6. Andronikou S, Kumbla S, Fink AM. Neonatal nasopharyngeal teratomas: cross sectional imaging features. Pediatr Radiol 2003;33:241-6. CrossRef

7. Roh JL. Transoral endoscopic resection of a nasopharyngeal hairy polyp. Int $J$ Pediatr Otorhinolaryngol 2004;68:1087-90. CrossRef

8. Abdulkader FI, Ganesan S, Al-rikabi AC, Al-shaikhky AS. Nasopharyngeal hairy polyp in association with West syndrome: case report and literature review. Int J Pediatr Otorhinolaryngol Extra 2006;1:306-9. CrossRef

9. Freitas Rda S, Alonso N, Azzolini Tde F, et al. Epignathus: two cases. Br J Oral Maxillofac Surg 2008;46: 317-19. CrossRef

10. Hossein A, Mohammad A. Huge teratoma of the nasopharynx. Am J Otolaryngol 2007;28:177-9. CrossRef

11. Maartens IA, Wassenberg T, Halbertsma FJ, Marres HA, Andriessen P. Neonatal airway obstruction caused by rapidly growing nasopharyngeal teratoma. Acta Paediatr 2009;98:1852-4. CrossRef

12. Turnbull C, Ruddy D, Barnicoat A. Nasopharyngeal teratoma and diaphragmatic hernia: no longer a random association but a new syndrome? Clin Dysmorphol 2009;18:131-4. CrossRef

13. Tiwari L, Baijal N, Puliyel JM. Nasopharyngeal teratoma as a cause of neonatal stridor. Indian Pediatr 2009;46:1097-8. PMID: 20061587

14. He J, Wang Y, Zhu H, Qiu W, He Y. Nasopharyngeal teratoma associated with cleft palate in newborn: report of 2 cases. Oral Surg Oral Med Oral Pathol Oral Radiol Endod 2010;109:211-16. CrossRef

15. Mirshemirani A, Khaleghnejad A, Mohajerzadeh L, Samsami M, Hasas-Yeganeh S. Congenital nasopharyngeal teratoma in a neonate. Iran J Pediatr 2011; 21:249-52.

16. Chariker M, Ford R, Morrison C, Theile A, Moeller K, Moriarty T. Pituitary duplication with nasopharyngeal teratoma and cleft palate. J Craniofac Surg 2011;22:755-8. CrossRef

17. Rangachari V, Aggarwal R, Jain A, Kapoor MC. Neonatal airway lesions: our experience and a review of the literature. J Laryngol Otol 2013;127:80-3. CrossRef

18. Koike Y, Uchida K, Inoue M, et al. Hairy polyp can be lethal even when small in size. Pediatr Int 2013; 55:373-6. $\underline{\text { CrossRef }}$

19. Bayır Ö, Güneri EA, Dilek M, Özer E, Çakmakçı H, Erdağ TK. Nasopharyngeal mature teratoma in the newborn. Turk Pediatri Ars 2014;49:257-60. $\underline{\text { CrossRef }}$

20. Han HH, Kim JH, Seo BF, Moon SH, Oh DY, Rhie JW. Huge nasopharyngeal teratoma with a cleft palate and bifid tongue in a patient with Pierre Robin syndrome. J Craniofac Surg 2014;25:e588-90. CrossRef

21. Mann GS, Heran MKS, Fandiño M, Ogilvie LN, Kozak FK. Nasopharyngeal choristoma: an unusual and rare cause of acute respiratory distress in the newborn. Case series and review of the literature. Int $J$ Pediatr Otorhinolaryngol Extra 2014;9:84-7. CrossRef

22. Radhakrishnan R, Calvo-Garcia MA, Lim FY, Elluru RG, Koch BL. Congenital salivary gland anlage tumor - in utero and postnatal imaging. Pediatr Radiol 2015; 45:453-6. $\underline{\text { CrossRef }}$

23. Menezes MP, Simao NM. Giant epignathus of the palate: a case report. J Bras Patol Med Lab 2015;51:339-43. $\underline{\text { CrossRef }}$

24. Hwang SY, Jefferson N, Mohorikar A, Jacobson I. Radiofrequency coblation of congenital nasopharyngeal teratoma: a novel technique. Case Rep Otolaryngol 2015;2015:634958. CrossRef

25. Alexander VRC, Manjaly JG, Pepper CM, Ifeacho SN, Hewitt RJ, Hartley BEJ. Head and neck teratomas in 
children--a series of 23 cases at Great Ormond Street Hospital. Int J Pediatr Otorhinolaryngol 2015;79: 2008-14. CrossRef

26. Ghatage S, Purohit A, Shah S, Karmarkar DP, Ambi P. Congenital nasopharyngeal teratoma with cleft palate in neonate. International Journal of Healthcare and Biomedical Research 2016;4:21-3. http://ijhbr.com/pdf/Jan\%202016\%2021-23.pdf

27. Jadhav SS, Korday CS, Malik S, Shah VK, Lad SK. Epignathus leading to fatal airway obstruction in a neonate. J Clin Diagn Res 2017;11:SDo4-5. CrossRef
28. Thong HK, Lamry NA, Kamalden TMIT, Devi U. Congenital nasopharyngeal teratoma: a potential cause of neonatal airway obstruction. RMJ 2018;43:562-4. https://www.rmj.org.pk/index.php?mno=264184

29. Aramesh MR, Majidinezjad S, Ilkhanopak $H$, Peyvasteh M. Nasopharyngeal teratoma in a neonate. J Neurol Res 2020;10:48-51. CrossRef

30. Kobayashi S, Yasumura K, Yabuki Y, Satake T, Maegawa J, Tanaka Y. Extended maxillotomy for nasopharynx access in infantile immature teratoma. $\mathrm{J}$ Craniofac Surg 2020;31:77-8. CrossRef 